\title{
Strategy for Developing Quality of Dakwah of Youth Muhammadiyah with Guidance and Counseling Service
}

\author{
Gusman Lesmana \\ Program Studi Bimbingan dan Konseling, University of Muhammadiyah Sumatera Utara, \\ Medan, Indonesia. Korespondensi: Jl. Mukhtar Basri No. 3 Medan, Email:

\section{gusmanlesmana@umsu.ac.id}

\section{Article Info}

History of Article

Submited April 2019

Approved July 2019

Published July 2019

\section{Key Word \\ Preaching, \\ Guidance And Counseling \\ Services.}

Kata Kunci

Latihan Asertive,

Kecerdasan Emosional

\begin{abstract}
Every individual has an obligation to spread goodness to all people to jointly do good things in life to create harmony and comfort in living together. Da'wah activities need to be trained and developed for individuals when they are young and adolescents so that da'wah skills are more mature and of good quality. This research was carried out with the aim of training da'wah to reconnect human nature with religion or make people aware of the truth of Islam and practice Islamic teachings. The results of this study indicate that in the process of helping, counselors need to foster, guide clients to better understand themselves, their abilities, abilities, and abilities. With this he will be guided so that he can design for the future.
\end{abstract}

\begin{abstract}
Abstrak
Setiap individu memiliki kewajiban untuk menyebarkan kebaikan kepada semua orang untuk bersama-sama melakukan hal-hal baik dalam hidup untuk menciptakan harmoni dan kenyamanan dalam hidup bersama. Kegiatan dakwah perlu dilatih dan dikembangkan untuk individu ketika mereka masih muda dan remaja sehingga keterampilan dakwah lebih matang dan berkualitas baik. Penelitian ini dilakukan dengan tujuan untuk melatih dakwah untuk menghubungkan kembali sifat manusia dengan agama atau membuat orang sadar akan kebenaran Islam dan mempraktikkan ajaran Islam. Hasil penelitian ini menunjukkan bahwa dalam proses membantu, konselor perlu membina, membimbing klien untuk lebih memahami tentang diri mereka sendiri, kemampuan, kemampuan, dan kemampuan mereka. Dengan ini dia akan dibimbing sehingga dia bisa mendesain untuk masa depan.
\end{abstract}

\section{Citation Info}

Lesmana, G., dan Deliati (2019). Strategy for Developing Quality of Dakwah of Youth Muhammadiyah with Guidance and Counseling Service. In Biblio Couns: Jurnal Kajian Konseling dan Pendidikan, 2(02), 61-73. 


\section{INTRODUCTION}

Communities throughout the world are now aware of it or not, individual lives are characterized by transitions that are traditionally, often considered very important. In addition to a view of the level of time, individuals are also viewed from their health in living life. Health behaviors that are shown by certain individuals or community groups have been highlighted.

Da'wah of Islam as an effort to invite and guide people to the path of goodness and piety is faced with various problems of human life that are increasingly complex. Various humanitarian cases that arise related to psychological, social, political, socioeconomic and socio-cultural aspects are increasingly felt in life. Among the cases that arose were the widespread outbreak of various community diseases, family problems, mental tension (nervousness), behavioral problems (disturbing the community), alcoholism, narcotics and drug abuse and so on. In addition to the socio-economic pressures that hit people's lives so that it can cause various moral violations that disturb peace, the declining factor of religious practice is the main factor that needs to be overcome.

In this context, Islamic da'wah has concepts and laws that govern human life in society. One of the methods of da'wah that the Prophet had applied. is the method of Guidance and Counseling or Guidance and Extension (Da'wah wal-Ershad). In some histories found, he has provided guidance to friends and Muslims in general in various aspects of life, both concerning religious issues and outside religion. Robert L. Gibson said that in ancient civilizations, philosophers, temple priests, royal priests, fortune tellers and representatives of divinity and religion were believed to have an important function of giving advice and offering counseling. The historical roots of the development of human potential can be recognized by ancient Greek society who emphasized the development and strengthening of individuals through education, so that all citizens can fulfill the role that reflects the greatest potential for themselves and for their communities.

In connection with that, Counseling is an effort to help clients with the aim that clients can take their own responsibility for the various problems they face.

In counseling, the counselor is in charge of studying, discussing the symptoms of psychiatric life, both from the da'i and mad'u who are involved in proselytizing processes so that they help to find effective new methodologies in preaching based on the needs of human life. By paying attention to mad'u's psychology along with his life needs, the preaching message delivered by the preacher will be easily accepted and will be carried out by mad'u because it touches and satisfies his spiritual life.

In carrying out the missionary duty, a Da'i is faced with the fact that individuals who will be accused of having diversity in various ways. This diversity will give a different pattern in accepting da'wah (da'wah material) that reacts to it, because that is to make the Da'i's effort to be effective in proselytizing to understand the Mad'u that will be faced. In other words, a Da'i is required to master the human psyche as individuals and group members. Indeed the essence of da'wah lies in the prevention of psychological illnesses by inviting, motivating, stimulating and guiding individuals to 
be healthy and prosperous in their souls and bodies, so that they can accept religious teachings with full awareness and can carry out religious teachings in accordance with the demands religious law. Counseling is a process of helping but not just giving advice. In the process of helping, counselors need to foster, guide clients to better understand about themselves, their abilities, abilities, and abilities. With this he will be guided so that he can design for the future. All client decisions and choices are not from the counselor but from the client itself. The counselor's role is only to guide the client in the process of making decisions and choices.

In the context of da'wah, guidance and counseling is one form of method that has been applied by scholars in preaching, both personal, family and community guidance. Guidance in matters of psychological ethics, psychotherapy and behavior, career guidance, Thibbun Nabawi, family counseling and especially in matters of religion. This shows that the scholars have functioned as spiritual guides for their people. In this connection the pesantren are at the center of Guidance and Counseling which play an important role in dealing with several cases that occur in the community. Islamic boarding schools have become the center of the spread of Islam and have become a center of consultation for spiritual guidance of students and the community. The scholars are religious educators who are always familiar with students and the community to deal with various problems. Active scholars accompany the santri and the community in the face of disasters and individual and social diseases in general.

From some of the descriptions above, from understanding to the purpose of da'wah and the duty of a Da'i. Then the relationship of counseling in preaching, we can analyze that a preacher in this case a Da'i in carrying out his duties in the field must find a lot of diversity in various ways. Like thoughts (ideas), experience, personality, etc., therefore, a Da'i inevitably has to learn a little more about counseling and its application in life. Thus the purpose of preaching can be conveyed on target, and can also avoid the occurrence of prejudice against Mad'u or vice versa. So that the da'i message delivered by Da'i can be accepted by Mad'u with an open and sincere heart.

\section{RESEARCH METHODS}

This study uses a descriptive quantitative approach. Research will describe the context of da'wah and the guidance and counseling approach. The population in this study were Muhammadiyah youth and youth in the City of Simalungun District. The instrument used is a Likert scale model. Test the validity of the research instrument through the content validity test using Pearson Product Moment by correlating grain scores and total scores and reliability testing using the Cronbach Alpha formula. Furthermore, the data obtained were analyzed using the Pearson Product Moment test to answer the hypotheses determined in this study. 


\section{RESULT AND DISCUSSION}

\section{Results}

The results of the analysis in its development, the term counseling is considered more appropriate than counseling for guidance and mentoring practices for someone who is in need of assistance in solving problems. So, began to develop various studies in the field of guidance and counseling with reference to the theories that have been studied in various literatures of Western Counseling thought. It also includes counseling in various psychological approaches such as Psychodynamics, Behavioral, Humanistic, Client Centered, Rational Emotive Behavioral, Cognitive, and many more. The results of this study are reinforced by Myers's theory (in Walgito, 1999) that behavior is something that will be much influenced by the environment.

Likewise the attitude expressed is also something that is influenced by the surroundings. People cannot measure attitudes directly is the attitude that appears, and the attitude that appears is behavior. This is in line with the attitude and behavior of da'wah which must be adapted to the needs of the client to guarantee the quality expected from the process of the missionary process.

Based on the verification of the research data, all data obtained from the results of administration of community members deserve to be processed. Learning innovations in the teaching lectures that will be carried out and expected to be able to contribute are learning based on guidance and counseling theory that utilizes individual personality theory in carrying out its activities in the teaching and learning process both the study of the youth and the instructor which is then connected into a unity in effective interpersonal relationships through learning based teaching activities. The more innovations that are raised in meetings, the greater the assessment of the process and results of the study and the learning that is done.

For the sake of fluency and improvement in the quality of da'wah, it requires the support of various parties including teaching staff and community members to collaborate in making da'wah that will be carried out resulting in the spread of quality Islamic teachings.

\section{Discussion}

Islamic guidance and counseling activities are still unknown to the public. However, some Muslim scientists, especially in Indonesia, such as Ahmad Mubarok, Dadang Hawari, Anwar Sutoyo, Hanna Jumhana Bastaman, Hamdan Bakran, and many more have developed Islamic counseling guidance. Islamic Guidance and Counseling is essentially an assistance and assistance service activity for an expert on individuals or groups in developing personalities and / or solving a problem with a psychological approach. Psychological approach as an approach because the problems faced are very much related to individual or group psychological problems caused by a life problem. Based on Islam, the counselors and assistants try to provide assistance in solving problems faced by someone. It seems that da'wah activities and Islamic counseling are two different things. But in fact both can be met at the point of destination and the process of conveying a value of life and religious values to others with the purpose of enlightened someone with these values. Thus it will make 
someone better in living a religious life and understanding the application of faith in the context of problem solving.

Anwar Sutoyo explained that Islamic counseling essentially helps a person to return to his natural consciousness (2013: 22). The awareness of fitrah contains the intention of human consciousness that he has the potential to think, the ability to understand problems well so that he also has the opportunity to reflect and evaluate himself as the beginning to solve a problem.

Referring to the notion of Islamic counseling that Anwar Sutoyo formulated that Islamic counseling is actually to build client awareness on how to apply faith in daily life, apply faith in efforts to solve problems, so that a believer will truly feel the joy of faith, Islam, and ihsan ( 2013: 149). This will shape the character of Muslim personalities who have self-balance and will be influential in their ability to be wise in facing life's problems. That condition can prevent a person from the conditions of despair and anxiety in the midst of a problematic life.

Training at the Muhammadiyah Youth Association as an autonomous Muhammadiyah organization, always carrying out positive activities in life, and organizing movements and business charities that are in line with the field chosen are students and adolescents in both Muhammadiyah organizations and the community in general including Al-Islam preaching activities.

Resistance from various parties, including Muhammadiyah, towards efforts to establish a forum or organization for Muhammadiyah students is actually a reflection of history and politics in Indonesia that occurred at the beginning of this idea was rolled out.

a. Optimizing the implementation of the leadership working mechanism in accordance with the work program supporting the development of da'wah programs.

b. Conduct youth coaching as young dai 'in Muhammadiyah schools through socialization of Guidance and Counseling-based da'wah coaching

c. Establish cooperation with schools and the Disdakmen Assembly in the context of youth training in preaching

d. Hold workshops, discussions and studies on effective cadre mechanisms

e. Carry out da'i training and training that supports the formation of da'wah cadres.

f. Improve insight into da'wah activities and models by conducting training studies

Fostering and enhancing understanding, appreciation and practice of Islam through meeting forums (study)

\section{CONCLUSION}

Based on the findings and discussion of the results of the study, conclusions can be put forward. There are several terms in activities and characters in the pattern of counseling relationships. as well as in da'wah activities, several components in counseling activities include: 1) people who provide counseling (counselors); 2) individuals or groups that receive counseling (counselees / clients); 3 ) the problem is to be resolved; 4) the purpose of counseling is according to the problem as a specific 
goal and the general purpose of the nature of counseling activities; 5) method;6) media; and the character of the counseling relationship.

From the counseling component, it is clear there are no components or elements of counseling material, but what exists is a problem that is about to be resolved. Through exposure to the problem from the counselee, a new counselor will convey what the counselee must understand and realize to help him solve the problem. So, what will be delivered (counseling material) clearly refers to the needs of the counselee based on the problems expressed by the counselee. In the counseling material that a counselor can simultaneously fill it with messages of value in Islamic teachings which are the rationale and the basis for building awareness and understanding of the counselee to analyze and resolve the problem.

\section{REFERENCES}

Azwar, Saifuddin. 2005. Penyusunan Skala Psikologi. Yogyakarta. Pustaka Pelajar.

Geldard, Kathryn dan David Geldard, 2008, Membantu Memecahkan Masalah Orang Lain dengan Teknik Konseling, diterjemahkan Agung Prihantoro, Yogyakarta, Pustaka Pelajar

Hawari, Dadang, 2014, Teknik Konseling: Rambu-rambu Konsultasi, Jakarta, Badan Penerbit FKUI

Lubis, Syaiful Akhyar, 2007, Konseling Islami, Yogyakarta, eLSAQ Press

Mubarok, Achmad, 2002, Al-Irsyad an-Nafsiy: Konseling Agama Teori dan Kasus, Jakarta, PT. Bina Rena Pariwara

Roslaini, "Penggunaan Bahasa dalam Konseling" , Jurnal Konselor, Tahun 1, No.2, Juli 2011

Sutoyo, Anwar, 2013, Bimbingan Konseling Islami (Teori dan Praktik), Yogyakarta, Pustaka Pelajar

Taylor, Shelley E (1999), Health Psychology, Singapura; Mc.Graw Hill International.

Watson Dan Tregerthan (1994), Introduction To Psychology, New York; Mc.Graw Hill Book Company Inc. 